\title{
EUROPEAN CERTIFICATE OF SUCCESSION
}

\author{
M. PĂTRĂUȘ, I-M. OFRIM
}

\author{
Mihaela PĂTRĂUȘ \\ associate professor, $\mathrm{PhD}$.,University of Oradea \\ Faculty of Law, Department of Public Law, Romania

\section{Ionița Maria OFRIM - Judge}

\section{ABSTRACT}

The newly created European Certificate of Succession is applicable in almost the entire EU. It is primarily used to verify an heir's status and is designed to serve alongside the existing national inheritance certificates (such as the German Erbschein), making it easier for heirs to settle inheritance matters abroad. This EU Succession Regulation does not, however, affect the provisions of individual Member States in the areas of substantive inheritance law (e. g. the question of who is a legal heir) and inheritance tax law.

This paper aims to analyze how the regulation of the European inheritance certificate interacts with the regulation of the national inheritance certificate. Thus it does not replace documents such as the Romanian inheritance certificate but is rather a supplementary inheritance document.

KEYWORDS : European Certificate of Succession, succession case, heir, transnational succession cases, habitual residence, disposition of property upon death.

\section{INTRODUCTORY CONSIDERATIONS}

Regulation (EU) 650/2012 introduced new rules of jurisdiction in matters of succession, applicable in all Member States. However, these rules apply only to the courts and other authorities and legal professionals with jurisdiction over inheritance matters, who exercise judicial powers or act on the basis of the delegation of powers by a judicial authority or act under the control of a judicial authority.

The diversity of the judicial organization between the states of the European Union is known and clearly observed with respect to the competent authorities in the different Member States. This legal variety of the competent authorities in the field of inheritance and the fact that they have different sovereign powers impede the universal effect of the court decisions in this matter or of the authentic acts and of the certificates issued. Their cross-border effects depend on the procedures for recognition, exequatur, and over-legalization, procedures that can be initiated and made often difficult either by bullshit or exaggerated nationalism.

The advent of the European Certificate of Succession ("ECS") has also proven to be an extremely important component of the European inheritance law system. The new solution 
was highly desired because the previous practice of documenting rights to inheritance was extremely varied. ${ }^{1}$

Regulation (EU) no. 650/2012 aims to avoid or accelerate all these time-consuming procedures, regulating both the recognition of court decisions in succession matters, or of authentic acts, as well as their enforced execution and the European Certificate of Succesion.

Regulation (EU) 650/2012 introduces this new instrument at Member State level - the European Certificate of Succession - intended for use by heirs and executors who must prove their status in another Member State or exercise their rights or duties.

Major innovation in European inheritance law, the European Certificate of Succession is a standard form designed to allow the heirs, legatees, executors or administrators of the inheritance to prove their quality and rights (art. 63), in open successions starting on August 17, 2015. Materializing the freedom circulation of judgments, it facilitates the efficient and rapid resolution of succession problems, especially due to its probative and legitimation effects $^{2}$. The purpose of introducing this instrument at the level of the Member States has been highlighted in recitals (7) - (9), (27), (32), (34), (59) and (67) of Regulation no. $650 / 2012$, of which the following results:

(32) In order to simplify the lives of heirs and legatees habitually resident in a Member State other than that in which the succession is being or will be dealt with, this Regulation should allow any person entitled under the law applicable to the succession to make declarations concerning the acceptance or waiver of the succession, of a legacy or of a reserved share, or concerning the limitation of his liability for the debts under the succession, to make such declarations in the form provided for by the law of the Member State of his habitual residence before the courts of that Member State. This should not preclude such declarations being made before other authorities in that Member State which are competent to receive declarations under national law. Persons choosing to avail themselves of the possibility to make declarations in the Member State of their habitual residence should themselves inform the court or authority which is or will be dealing with the succession of the existence of such declarations within any time limit set by the law applicable to the succession.

(67) In order for a succession with cross-border implications within the Union to be settled speedily, smoothly and efficiently, the heirs, legatees, executors of the will or administrators of the estate should be able to demonstrate easily their status and/or rights and powers in another Member State, for instance in a Member State in which succession property is located. To enable them to do so, this Regulation should provide for the creation of a uniform certificate, the European Certificate of Succession (hereinafter referred to as 'the Certificate'), to be issued for use in another Member State. In order to respect the principle of subsidiarity, the Certificate should not take the place of internal documents which may exist for similar purposes in the Member States.

In national law, the European certificate of heir is regulated by Law no. 206/2016 for the completion of the Government Emergency Ordinance no. 119/2006 regarding some measures necessary for the application of some Community regulations from the date of

\footnotetext{
${ }^{1}$ Mariusz Załucki, Attempts to Harmonize the Inheritance Law in Europe: Past, Present, and Future, 103 Iowa L. Rev. 2317 (2018), article available at: https://ilr.law.uiowa.edu/print/volume-103-issue-5/attempts-toharmonize-the-inheritance-law-in-europe-past-present-and-future/;

${ }^{2}$ Dan A. Popescu, Guide to private international law in the field of succession, Notarom Publishing House, Bucharest, 2015, pp. 26;
} 


\section{EUROPEAN CERTIFICATE OF SUCCESSION}

Romania's accession to the European Union, as well as for the modification and completion of the Law of public notaries and of the notarial activity no. 36/1995.

\section{CONCEPT, CONTENT AND EFFECTS}

The European Certificate of Succession represents the document that is fully recognized in all European Union states except the United Kingdom and Denmark, which allows the heirs, legatees, executors and administrators of the estate to prove their quality and to exercise their duties in other states of the Union. European (Articles 62 and 63 of the Regulation). This certificate is optional, it does not replace the internal documents for similar purposes of each Member State, but once issued by a Member State it can replace these internal documents in the issuing State.

The existence of a European Certificate of Succession necessarily implies the debate of a succession that includes an element of foreignness, such as the existence of a good from the succession mass on the territory of another Member State. If the goods / goods are in the territory of a third country of the European Union, the certificate of national heir is subject to recognition (the procedure of the European certificate does not apply) being necessary to follow the procedure of recognition by the jurisdiction of the court.

The content of the certificate is outlined in art. 68 of Regulation (EU) no. 650/2012. Depending on the characteristics of the succession case, this certificate may include up to fifteen elements of which we mention: the name and address of the issuing authority, the elements justifying the competence of the respective authority, the date of issue, information on the applicant, deceased and beneficiaries, data on the matrimonial property regime of decuius, the law applicable to the succession, the character of the inheritance and the share or the list of rights and property belonging to each heir as well as the powers of the executor or of the administrator of the estate. The standard form is set out in Annex no. 5 of the Implementing Regulation (EU) no. 1329/2014 and bears the name of the Form no. V. This form has five annexes, also provided by the implementing regulation.

More importantly, the European Certificate of Succession must contain information regarding the elements from which the rights and / or prerogatives of executors or administrators of the inheritance are derived, to heirs and legatees, to the existence of a matrimonial agreement, an eventual will, an statements of acceptance or renunciation of succession. He should mention the share of the inheritance and the corresponding rights due to each heir, the eventual list of assets due to a certain heir or legatee, but also the possible incidental restrictions (an inalienability, a dismantling of the property, the possible reducibility of the rights of the legatees due to existence ) for this, it is imperative to consider the applicable succession law ${ }^{3}$.

The effects of the certificate are described in detail in art. 69 of the regulation. Thus, it produces effects directly in each Member State bound by the regulation and is presumed to faithfully attest to all the elements mentioned. At the same time, it cannot be requested to legalize it or another similar formality for it to take effect. Moreover, the certificate cannot be controlled in a state other than that of origin from the perspective of the competence of the issuing authority, the observance of the public order of private international law and cannot be the object of an appeal in the state where it is invoked. Also regarding the effects produced by the European Certificate of Succession, we mention that they are especially of a probative

\footnotetext{
${ }^{3}$ Dan Andrei Popescu, op.cit., p. 103-104;
} 
nature. These mainly concern elements established according to lex successionis (determining the heirs / legatees, the rights of each, the powers of the executor or the administrator), but also issues that, even governed by their own laws, directly influence the content of the certificate (eg conditions of the certificate). fund of a disposition for cause of death) ${ }^{4}$.

Subsequently, also in the light of the effects of the certificate, the persons designated herein as heir, legatee, administrator or executor are presumed to have the status and rights mentioned in the certificates and the third parties who have entered into legal operations under the information in the certificate are protected, with unless they knew that the information was false or did not know this because of their gross negligence.

At the same time, wishing to promote the European Certificate of Succession, the Regulation allows access to public records through it: according to art. 69 par. 5, the European certificate of heir constitutes a valid title (in the Romanian, Italian, Spanish versions), respectively a valid document (in the French, English, German, Portuguese versions) for the registration of the transfer of the succession assets in the corresponding registers of a state member (land books, trade register, register of inventions or trademarks OSIM), without the need for a particular procedure. However, the rule must be correlated with that in art. 1§2.lit.1), which excludes from the scope of the regulation the problems regarding the entries in the public registers. This allows the safeguarding of national requirements (especially regarding the form of the documents presented, quite strict) and will require, at least sometimes, the appreciation of the equivalence of nature between the European certificate and the documents required by national law.

\section{OPTIONAL CHARACTER}

According to art. 62 of the regulation, the use of the European heir certificate is optional; it can be used in conjunction with national certificates of heir or other internal documents used for similar purposes, which are not substituted, or even in countries where such certificates could not previously be issued (eg Italy). If its issue is conditioned by the certificate's vocation to be used in other Member States, it will produce effects including in the state of origin (art. 62, paragraph 3, second sentence); avoiding a possible reverse discrimination, the solution acquires a particular importance especially in the states that do not know the institution of the heir certificate, with whose internal successor law it interacts, and for this reason it has been criticized.

\section{RELATIONSHIP WITH THE NATIONAL CERTIFICATE OF HEIR}

The relationship between the European Certificate of Succession and the National Certificate of Inheritance is not fully clear. Thus, the regulation does not specify which of these should take precedence in case of conflict or how it should be done when authorities from different states were requested at the same time for their issuance. The possible punctual interventions of the European Court of Justice will clarify things, but in their absence the uncertainty persists.

The relationship between these two certificates can be highlighted also from the point of view of the functions performed by the two acts. The certificate of heir, including the European one, fulfills three functions in the law: a means of proving the quality of heir, a

\footnotetext{
${ }^{4}$ Ioana Olaru, European law of international successions. Practical Guide, Notarom Publishing House, Bucharest, 2014, p. 193;
} 


\section{EUROPEAN CERTIFICATE OF SUCCESSION}

means of proving the right of ownership of the accepting heirs over the share due to them from the succession assets and a means of securing the non-heirs' heirs.

Thus, it can be stated that the two certificates fulfill the same functions, this, since, art. 63 paragraph (2) of this normative act has the following meaning: "the certificate can be used, in particular, to prove one or more of the following: a) the status and / or the rights of each heir, or, as the case may be, of each of the said legatees in the certificate and the respective shares of the inheritance inheritance; b) the attribution of a certain good or of certain goods that are part of the inheritance patrimony to the heir / heirs or, as the case may be, to the legatee mentioned (the legatees mentioned) in the certificate; c) the attributions of the person mentioned in the certificate as executor or administrator of the estate ". Thus, it seems that the European certificate of heir represents, as well as the national one, a means of proving the quality of heir and the property right of the universal heirs and with universal title on the quota that is appropriate to each one, respectively of the legatee by title particularly on individual assets. Referring to this type of certificate, we believe that we are not mistaken if we affirm that it is merely a title property lato sensu and, necessarily, a means of proof of ownership over certain parts of the inheritance, in the case of universal heirs and title universal, respectively on some particular goods, in the case of the binders with a particular title

The relationship between the two certificates is also confusing from the perspective of domestic law, since in Law no. 206/2016 for the completion of the Government Emergency Ordinance no. 119/2006 regarding some measures necessary for the application of some Community regulations from the date of Romania's accession to the European Union, as well as for the modification and completion of the Law of public notaries and of the notarial activity no. 36/1995 where in art. 3 a. (1) it is provided that the European Certificate of heir shall be issued, in accordance with the provisions of Chapter VI of Regulation no. 650/2012, at the request of any of the persons provided for in art. 63 paragraph (1) of the regulation, by the notary public who issued or in the archive the certificate of heir is kept. Thus, it can be interpreted that the issuance of the European certificate of heir is conditional upon the issuance of the national certificate of heir, the procedure being a contradictory one and conditioned by the agreement of all the heirs, a solution that violates the provisions of Regulation 650/2012, according to which the European certificate can be issued at the request of any heir, only with the notification of the other heirs.

\section{COMPETENT AUTHORITY}

According to art. 64, the European Certificate of Succession may be issued not only by the judicial authorities (as defined in Article $3 \S 2$ of the Regulation), but also by other authorities which, under national law, are competent in matters of succession; this means that even notaries from countries such as Romania, the Czech Republic, Austria (where they are not considered as "judicial authorities") qualify for the issuance of the certificate. The international competence will be assessed in accordance with the general rules of competence established in chapter II of the regulation (art. 64 paragraph 1), and the internal territorial competence according to the rules in force in the state of the forum. The certificate must contain a statement of competence.

\footnotetext{
${ }^{5}$ Bogdan Pătrașcu, Ilioara Genoiu, Some reflections on the functions of the inheritance certificate, including the European certificate, in LEGAL STUDIES AND RESEARCH Year 5 (61), Nr. April 2 - June 2016, p.15;
} 
A hypothesis debated in the doctrine refers to the competence of the notaries public in Romania to issue the European certificate of heir, in the light of the provisions of the Regulation. In the doctrine it was emphasized that in some states of the Union, the notaries public have jurisdiction or act on the basis of delegation from a court (which is why the regulation includes them in the concept of "courts"6), while in others, public notaries are authorities independent of the courts, without jurisdictional powers, but with preventive role and guaranteeing the security of the civil circuit ${ }^{7}$.

The certificate can be issued only by the State whose courts are internationally competent to settle the succession with an element of foreignness according to articles $4,7,10$ and 11 of the regulation. Therefore, the international competence regarding the issue of the Certificate is:

a). The State in which the deceased was habitually resident at the time of death;

b). The state of citizenship of the deceased in the case in which he designated the law of this state as competent to regulate his succession according to art. 22 of the regulation (the cases in which the jurisdiction falls to this state are detailed in article 7 of the regulation);

c). The Member State in whose territory the successor property is located, in the event that the deceased did not reside in the EU, at the time of death, if the respective state was the state of nationality of the deceased at the time of death or if he was the national of the citizenship, was the state of the habitual residence of the deceased in at least part of the interval of the last five years before death. In these situations, the Member State is competent to issue an EMC for self-defense;

d). To the Member State in whose territory successor assets are located, but only for those goods, if the residence of the deceased is outside the United States, none of the other conditions of the preceding point are met;

e). Exceptionally, the Member State which has sufficient connection with the succession the situation in which the succession procedure cannot be initiated and can be carried out reasonably or is impossible in the third state which has a close connection with the succession. Here the Member State acts as a forum of necessity.

The public authority of the international competent state to issue the Certificate may be the competent court (within the extended meaning of the term in Article 3 of the regulation) or another authority which, according to the national law, is competent in the matter of succession. Corroborating this norm with the provisions of art. 94 lit. j Code of civil procedure and of art. 12 letter $\mathrm{c}$ of the Law on public notaries no. 36/1995, we conclude that the Romanian authorities competent to issue a European certificate in situations where Romania has international jurisdiction over the succession are the court, the court (only for challenging the certificates issued by the judges, as will be (see below) and notaries public.

The rules of internal territorial jurisdiction will determine exactly which court (or court) and which public notaries are territorially competent to issue the Certificate. For the

\footnotetext{
${ }^{6}$ Cosmin Dariescu, European Conflict Norms on European Heritage and Certificate of Inheritance, article available ,https://www.academia.edu/16703430/NORMELE_CONFLICTUALE_EUROPENE_PRIVIND_MO\%C8\%98T ENIREA_\%C8\%98I_CERTIFICATUL_EUROPEAN_DE_MO\%C8\%98TENITOR:

${ }^{7}$ Alexandra Irina Danila, Andrada Raluca Tanse, Decision of the Court of Justice of the European Union in case c-20/17 and its impact on the issuance by the notaries of the internal certificates of heir, based on the law no. $36 / 1995$ of the notaries public and of the notarial activity, available at https://buletinulnotarilor.ro/decizia-curtiide-justitie-a-uniunii-europene-in-cauza-c-20-17-si-impactul-acesteia -asupra-release-of-the-notaries-to-internal certificates-of-heir-in-law-based no-36-1995-a-notary-public/;
} 


\section{EUROPEAN CERTIFICATE OF SUCCESSION}

exact finding of the Romanian public annotator competent to issue the Certificate, the articles 15 and 101 of Law no. 36/1995, the form republished in 2014. The rules in art. 101 of the Law no.36 / 1995 distributing the successive causes (including those with an element of foreignness) in the territory between the notaries public in Romania are mixed in nature. They are both norms of internal territorial competence but also norms of international competence. Moreover, the doctrine accepts the use of the territorial jurisdiction rules for finding the competence in private international law in those systems of law that do not have special regulations regarding the competence of international law (the case of Romania for the international competence of notaries public ${ }^{8}$.

This analysis also takes into account recital 20 of the Regulation, according to which „This Regulation should respect the different systems for dealing with matters of succession applied in the Member States. For the purposes of this Regulation, the term 'court' should therefore be given a broad meaning so as to cover not only courts in the true sense of the word, exercising judicial functions, but also the notaries or registry offices in some Member States who or which, in certain matters of succession, exercise judicial functions like courts, and the notaries and legal professionals who, in some Member States, exercise judicial functions in a given succession by delegation of power by a court. All courts as defined in this Regulation should be bound by the rules of jurisdiction set out in this Regulation. Conversely, the term 'court' should not cover non-judicial authorities of a Member State empowered under national law to deal with matters of succession, such as the notaries in most Member States where, as is usually the case, they are not exercising judicial functions."

However, these rules apply only to the courts and other authorities and legal professionals with jurisdiction over inheritance matters, who exercise judicial powers or act on the basis of the delegation of powers by a judicial authority or act under the control of a judicial authority (3). The rules of jurisdiction do not apply, from our point of view, to the Romanian public notaries who issue the certificate of heir of national law under Law no. $36 / 1995$ of the notaries public and of the notarial activity, republished, since they do not fit in any of the above mentioned hypotheses.

This opinion starts from the provisions contained in the Regulation, which states that the notion of "court" must be viewed in a broad sense, not only referring to the courts themselves, but also to notaries from some states that in the field of succession exercise judicial attributions such as the courts, as well as notaries who in other states exercised these powers by delegating the date of the courts, but not notaries who within the meaning of our national legislation, who do not exercise their activity under the control and based on the delegation of the court.

Of course, we were wondering where the Romanian notaries are positioned? They do not, within the meaning of the Regulation, exercise judicial powers. Thus, they are exempted from the rules of competence of the Regulation (art. 4 et seq.). Although they are exempted from the rules of competence of the regulation, they are governed by the rules regarding the locality of the successions, by the rules regarding the determination of the law applicable to the successions (art. 21 et seq.).

As a result, the Romanian public notary notified of a succession with an element of foreignness, in which the successor only requests the issuance of the inheritance certificate of national law under Law no. 36/1995 of the notaries public and of the notarial activity is not

\footnotetext{
${ }^{8}$ Ion P. Filipescu, Private International Law, Vol. II, Actami Publishing House, Bucharest, 1995, p.209;
} 
kept by the rules of competence stipulated in art. 4, 7, 10 and 11 of the Regulation. In order to debate the succession and issue of the inheritance certificate of national law, the notary public will verify his competence on the basis of art. 954 of the Civil Code and art. 15 lit. a) and b) and art. 103 of Law no. 36/1995 and will be able to issue the certificate of national law, for example, even in the situation where the deceased had his last domicile and habitual residence in another Member State, if he left goods in Romania.

In order to ensure a uniform application of the provisions of the Regulation in the Member States, from the beginning of the application of the Regulation and until now, certain provisions of it have been subject to interpretation by the Court of Justice of the European Union (CJEU).

By a recent decision of 21 June 2018 in Case C-20/17Oberle ${ }^{9}$, The CJEU ruled that a court in a Member State to the Regulation is governed by the rules of jurisdiction provided for by the Regulation not only when issuing the European Certificate of Succession or when giving a judgment in the matter of succession, but also when, following a non-contentious procedures, issue a certificate of heir of national law (8).

The question arose whether this decision of the Court should be interpreted in the sense that notaries who are not assimilated to the courts, under the conditions of art. 3 paragraph (2) of the Regulation, could no longer issue the national certificates of heir in succession with foreign element, if the deceased had his habitual residence in the territory of another Member State.

As I have shown above, I have considered in the sense that the Romanian public notary, not being kept by the rules of competence of the Regulation no. 650/2012, could issue an internal certificate of heir, even when the competence of issuing the European heir certificate would belong to the authorities of another Member State applying the Regulation.

This opinion also results from the interpretation of the aforementioned decision considerations, whereby the Court responded to the parties' conclusions. Thus, paragraph 48 of the judgment (14), for example, viewed independently, could lead to the interpretation that the national certificate of heir must be issued in compliance with the rules of competence provided by the Regulation. In fact, this point contains the Court's answer to one of the claims made by the referring court, Germany and France, according to which it can be deduced from the inclusion in the Regulation of Article 64 that Article 4 does not determine the competence regarding the procedures for issuing national certificates of Crown (15). Of course, it is about the certificates of heir issued by the courts, and not the certificates issued by the extrajudicial authorities, which, in our opinion, were not considered by the Court.

The judgment of the CJEU establishes that courts or authorities assimilated to the courts will not be able to issue national certificates of heir, in non-litigation procedures, when another court in a Member State could attract general jurisdiction, based on art. 4 et seq. of the Regulation. This was also the interpretation adopted by other Member States. For example, in Hungary, the specific nature of the notarial procedure made the notaries to be assimilated to the courts, under the conditions of art. 3 paragraph (2) of the Regulation, being notified to the Commission and included in the list provided in art. 79. As such, although the notarial succession procedure that ends with the issuance of the national certificate is noncontentious, the Hungarian notaries receive the succession and issue the act of finalizing the

${ }^{9}$ http://curia.europa.eu/juris/document/document.jsf?text=\&docid=203223\&pageIndex=0\&doclang=ro\&mode $=1 \mathrm{~s}$ $\underline{\mathrm{t} \& \text { dir }=\& \text { occ }=\text { first } \& \text { part }=1 \& \operatorname{cid}=7092511}$ 


\section{EUROPEAN CERTIFICATE OF SUCCESSION}

succession procedure only in compliance with the rules of competence from art. 4, 7, 10 and 11 of the Regulation (16).

Prior to the CJEU judgment in the Oberle case, the doctrine offered two divergent solutions on how to determine jurisdiction in the issue of national certificates of heir. On the one hand, it was considered that the judicial authorities of the Member States are still competent to issue national certificates of inheritance under national law, even if they are not competent with regard to the succession as a whole. On the other hand, the issuance of a national certificate of heir was included in the scope of art. 4 of Regulation (EU) 650/2012.

Considering in particular the need to ensure coherence between the provisions on jurisdiction and those relating to the law applicable in this matter, as well as the principle of unity of succession, which implies the harmonization of the rules on the international jurisdiction of the courts of the Member States both in the litigation procedures and in the in the case of non-litigants, the Court of Justice of the European Union, in accordance with the conclusions of the Advocate General, interpreted art. 4 of Regulation (EU) 650/2012 in the sense that it also determines the jurisdiction of the courts in the matter of the procedures for issuing national certificates of heir.

The ECJ also emphasized that this interpretation "aims, in the interests of good administration of justice within the Union, to achieve this objective by limiting the risk of parallel proceedings before the courts of different Member States and any contradictions that may result from these ", such as the situation where the national certificate of heir would be issued by two judicial authorities from two different Member States.

In conclusion, we point out that this decision of the CJEU concerns only the national certificates of heir issued by a judicial authority, such as the courts, not those issued by the notaries public, the question of qualifying the notaries as a court being given in the judgment given in $\mathrm{C}-658 / 17 \mathrm{WB}^{10}$ of the CJEU, a case in which the preliminary question addressed to the Court sought to find out whether the documents issued in the succession procedure by Polish notaries, which were not assimilated to the courts, could be qualified as court decisions, with the consequence of re-framing them notaries as courts and the submission of their acts to the jurisdiction rules of art. 4, 7, 10 and 11 of the Regulation.

In resolving this case, the Court held that an inheritance certificate such as the one at issue in the main proceedings is not issued by a court, within the meaning of Article 3 (2) of Regulation no. 650/2012, this certificate does not, in accordance with paragraph 32 of this decision, constitute a "decision" in the matter of succession within the meaning of Article 3 (1) ( $g$ ) of this Regulation.

Therefore, the notarial succession procedure completed before an extrajudicial authority is still excluded from the scope of the rules of jurisdiction of the Regulation, and the issuance of the national heir certificate can be continued even if the notary public does not meet the criteria. of art. 4, 7,10 or 11 of the Regulation.

\section{PROCEDURE FOR ISSUING THE CERTIFICATE}

This involves a request, made by the person concerned (heir, legatee, executor, administrator), accompanied by documents of different nature (identity documents, birth certificates, marriage, death, marriage agreements, will, declarations of acceptance or

\footnotetext{
${ }^{10} \mathrm{http}: / /$ curia.europa.eu/juris/document/document.jsf?text=\&docid=214397\&pageIndex=0\&doclang=RO\&mode $=1$ st $\&$ dir $=\& o c c=$ first $\&$ part $=1 \&$ cid $=6760914$.
} 
renunciation in succession), in certified or original copies, containing relevant information regarding the applicant, the deceased and his family or the inheritance itself; the detailed list of the targeted information is provided in art. 65 (3) of the regulation.

It is not necessarily that they allow the international character of the succession to be established, since the certificate itself can be used later for the eventual collection of data in this regard; it is also irrelevant whether or not the succession has been definitively resolved. The issuing authority (which verifies its competence in advance, in accordance with the rules of Chapter II of the regulation) must actively examine the documents and information received, their force and probative value.

According to art. 67, once, considering the law applicable to the succession, the elements whose certification is desired have been established, the requested authority will issue the certificate without delay, using the standard form elaborated by the commission. The beneficiaries (the applicant, but also other persons interested in solving the succession) will have to be informed.

Two possible reasons for refusing to issue the certificate are expressly mentioned, but not limited by the legal text. The first concerns the existence of an appeal, formulated in a separate judicial procedure or directly in front of the requested authority, regarding the elements whose certification is desired; the refusal will not intervene automatically, the requested authority preserving the freedom, after verifying its serious character, to decide a possible release of a partial certificate, regarding only the uncontested data. The second reason for refusal, with more serious consequences, is the existence of a court decision on elements whose certification is desired, with which the certificate would not comply.

The issuing authority retains the European certificate of heir, after which it issues to the applicant and, upon request, any person having a legitimate interest, certified true copies, with a validity period of six months, which can be extended for duly justified exceptional reasons (such as the use of the copy in - a procedure that has not been completed). The issuance of new copies is possible (art. 70), unless the effects of the certificate are suspended.

The authority that issued such a certificate is exclusively competent for its rectification, modification or withdrawal (art. 71). The prompt information of all persons to whom certified copies have been issued is obligatory in any of these cases (art. 71§3) and the suspension of the effects of the European heir certificate is possible, at the request of the persons justifying a legitimate interest (art. $73 \S 1$.a.).

Any measure of issuance, rectification, modification, withdrawal or refusal to issue a European Certificate of Succession may be challenged before a judicial authority in the Member State in which the issuing authority is located. During these procedures, at the request of the persons contesting the decision and with the delayed information of the holders of certified copies, the judicial authority may temporarily suspend the effects of the European certificate of heir (art. $73 \S 1 . b)$.

\section{CONCLUSIONS}

Finally, we consider that this instrument is a major innovation in European inheritance law and contributes to fulfilling the purpose of facilitating the debate of successions with elements of foreignness, but there are still issues to be clarified by the Court of Justice of the European Union. to ensure the uniform application and use of this legal instrument.

Therefore, in order to fulfill the assumed objective - the harmonization of substantive inheritance law in the European Union in this half of the century-research of the common 


\section{EUROPEAN CERTIFICATE OF SUCCESSION}

principles which may become basis for the future European regulation must be carried already today. Only the determination of all common values at the foundation of each specific standard solution may facilitate a closer look and a possible attempt to design new, uniform regulations. Nevertheless, Europe's uniform inheritance law is still in its earliest stage, and all evidence indicates that this phase will last much longer than it should

\section{BIBLIOGRAPHY}

1. Alexandra Irina Danila, Andrada Raluca Tanse, Decision of the Court of Justice of the European Union in case c-20/17 and its impact on the issuance by the notaries of the internal certificates of heir, based on the law no. 36/1995 of the notaries public and of the notarial activity, available at https://buletinulnotarilor.ro/decizia-curtii-de-justitie-a-uniuniieuropene-in-cauza-c-20-17-si-impactul-acesteia-asupra-eliberarii-de-catre-notari-acertificatelor-interne-de-mostenitor-in-baza-legii-nr-36-1995-a-notarilor-publ/;

2. Cosmin Dariescu, The European Conflict Norms regarding the inheritance and the European Certificate of Succession, article available at https://www.academia.edu/16703430/NORMELE_CONFLICTUALE_EUROPENE_PRIVIN D_MO\%C8\%98TENIREA_\%C8\%98I_CERTIFICATUL_EUROPEAN_DE_MO\%C8\%98T ENITOR;

3. Ion P. Filipescu, Private International Law, Vol. II, Actami Publishing House, Bucharest, 1995;

4. Ioana Olaru, European law of international successions. Practical Guide, Notarom Publishing House, Bucharest, 2014;

5. Bogdan Pătrașcu, Ilioara Genoiu, Some reflections on the functions of the inheritance certificate, including the European certificate, in LEGAL STUDIES AND RESEARCH Year 5 (61), Nr. April 2 - June 2016;

6. Dan A. Popescu, Guide of private international law in the field of successions, Notarom Publishing House, Bucharest, 2015;

7. Mariusz Załucki, Attempts to Harmonize the Inheritance Law in Europe: Past, Present, and Future, 103 Iowa L. Rev. 2317 (2018), article available at: https://ilr.law.uiowa.edu/print/volume-103-issue-5/attempts-to-harmonize-the-inheritancelaw-in-europe-past-present-and-future/. 